\title{
Pemberdayaan Masyarakat Kelurahan Kedaung Kota Bandar Lampung Menuju Desa Tangguh Covid-19
}

\author{
Antun Rahmadi*1, Sutrio², Arie Nugroho3, Bertalina4, Dewi Sri Sumardilah5, Usdeka Muliani6, \\ Mindo Lupiana7, Roza Mulyani ${ }^{8}$, Endang Sri Wahyuni ${ }^{9}$, Sefanadya Putri10, Yulia Novika J.11, \\ Nawasari Indah Putri Sejati12 \\ 1,2,3,4,5,6,7,8,9,10,11,12Politeknik Kesehatan Tanjung Karang, Indonesia \\ *e-mail: antunrahmadi@poltekkes-tjk.ac.id ${ }^{1}$, sutrio@poltekkes-tjk.ac.id² ${ }^{2}$, arienugroho@poltekkes- \\ tjk.ac.id $^{3}$, bertalina@poltekkes-tjk.ac.id ${ }^{4}, \underline{\text { dewisrisumardilah@poltekkes-tjk.ac.id }}^{5}$, inideka@yahoo.co.id ${ }^{6}$, \\ mindo@poltekkes-tjk.ac.id ${ }^{7}$, rozamulyani10@yahoo.com ${ }^{8}$, end wahyuni71@yahoo.com ${ }^{9}$, \\ sefanadia@gmail.com ${ }^{10}{ }^{\text {,yulianovikaj@poltekkes-tjk.ac.id }}{ }^{11}$, nawasarips@gmail.com $^{12}$
}

\begin{abstract}
Abstrak
Penerapan protokol kesehatan terbukti efektif untuk mencegah penularan Covid-19. Partisipasi masyarakat menjadi kunci utama untuk mencegah penyebaran wabah Covid-19. Adaptasi kebiasaan baru perlu didukung dengan pengetahuan yang benar. Oleh karena itu masyarakat perlu diberikan edukasi yang memadai tentang masalah Covid-19 dan upaya pencegahannya. Sosialisasi protokol kesehatan kepada aparat pemerintahan kelurahan yang diikuti dengan penyuluhan dan konsultasi bagi sasaran khusus merupakan salah satu metode yang layak dilakukan. Sosialisasi secara klasikal terbukti dapat meningkatkan secara signifikan pengetahuan aparat pemerintahan kelurahan sebesar 42,3\% sedangkan penyuluhan informal dan berkala dapat meningkatkan pengetahuan masyarakat sebesar 52,03\%. Pemberian stimulus sarana pendukung pelaksanaan protokol kesehatan juga berkontribusi meningkatkan partisipasi masyarakat dalam melaksanakan protokol kesehatan.
\end{abstract}

Kata kunci: sosialisasi Covid-19, penyuluhan Covid-19, konsultasi Covid-19, protokol kesehatan

\begin{abstract}
The implementation of health protocols has proven effective in preventing transmission of Covid-19. Community participation is the main key to preventing the spread of the Covid-19 outbreak. The adaptation of new habits needs to be supported by correct knowledge. Therefore, the community needs to be given adequate education about the Covid-19 problem and efforts to prevent it. Socialization of health protocols to urban village government officials, followed by counseling and consultations for specific targets, is a feasible method. Classical socialization has been proven to significantly increase the knowledge of urban village government officials by 42.3\%, while informal and periodic counseling can increase public knowledge by 52.03\%. Providing a stimulus for means of supporting the implementation of health protocols also contributes to increasing community participation in implementing health protocols.
\end{abstract}

Keywords: Covid-19 socialization, Covid-19 counseling, Covid-19 consultation, health protocols

\section{PENDAHULUAN}

Coronavirus 2019 atau Covid-19 yang diketahui mulai ada dari pasar hewan di Wuhan, China merupakan pandemi yang telah mengakibatkan tingginya angka mortalitas di berbagai belahan dunia.[1] Virus ini telah berkembang ke seluruh dunia dengan kecepatan penyebaran yang sangat cepat.[2] Penyebaran virus Covid-19 saat ini semakin dipahami. Sifat Covid-19 yang mudah sekali menyebar antara manusia satu dengan lainnya. [3,4] Penyebarannya terjadi terutama antara orang melalui rute droplet (percikan) dari saluran pernapasan dan kontak.[5] Penularan droplet terjadi saat seseorang berada dalam kontak erat (dalam jarak 1 meter) dengan orang yang terinfeksi dan terjadi pajanan droplet saluran pernapasan yang kemungkinan terinfeksi, misalnya melalui batuk, bersin, atau kontak sangat erat dengan orang tersebut sehingga agen infeksi masuk melalui titik-titik seperti mulut, hidung, atau mata.[6,7] Penyebaran juga dapat terjadi melalui fomit di lingkungan langsung orang yang terinfeksi karena itu, penyebaran virus Covid-19 dapat terjadi secara langsung melalui kontak dengan orang yang terinfeksi atau secara tidak langsung melalui kontak dengan permukaan lingkungan langsung atau benda-benda yang digunakan untuk atau oleh orang yang terinfeksi.[8] 
Untuk mencegah penularan Covid-19 maka berbagai tindakan preventif mutlak harus dilakukan. Upaya preventif sejauh ini merupakan praktik terbaik untuk mengurangi dampak pandemi Covid-19, mengingat belum adanya upaya kuratif yang dinilai efektif dalam melawan virus SARS-CoV-2. Upaya preventif terbaik yang dilakukan adalah dengan menghindari paparan virus dengan didasarkan pada penerapan protokol kesehatan seperti penggunaan masker, mencuci tangan secara teratur dengan sabun atau desinfeksi dengan pembersih tangan yang mengandung setidaknya $60 \%$ alkohol, menghindari kontak dengan orang yang terinfeksi, menjaga jarak dari kerumunan orang, dan menahan diri dari menyentuh mata, hidung, dan mulut dengan tangan yang tidak dicuci.[9]

Partisipasi masyarakat menjadi kunci utama untuk pencegahan penyebaran wabah Covid-19. Pemerintah menganjurkan masyarakat untuk menerapkan social distancing (pembatasan sosial) dan physical distancing (pembatasan fisik) guna memotong rantai penyebaran virus tersebut. Partisipasi masyarakat dalam penanganan Covid-19 mempunyai peran yang sangat penting, masyarakat dapat berperan bukan saja sebagai objek tetapi juga sebagai subjek penanganan Covid-19. Partisipasi masyarakat pada dasarnya merupakan kesediaan secara ikhlas dari masyarakat untuk membantu kegiatan penanganan penyakit yang terjadi di daerahnya masing-masing agar penyebaran Covid-19 ini tidak semakin meluas.[10]

Kelurahan Kedaung merupakan salah satu dari 9 kelurahan yang ada di Kecamatan Kemiling, Kota Bandar Lampung dan merupakan kelurahan dengan wilayah terluas yaitu 652 ha atau $25,8 \%$ dari luas wilayah Kecamatan Kemiling. Secara administratif wiayah kelurahan dibagi menjadi 2 lingkungan dengan 12 RT. Bertolak belakang dengan luas wilayahnya, jumlah penduduk Kelurahan Kedaung adalah yang paling sedikit diatara kesembilan kelurahan di Kecamatan Kemiling. Dengan jumlah penduduk sebanyak 1.775 jiwa maka tingkat kepadatan penduduknya juga yang terendaah yaitu 211 per $\mathrm{km}^{2}$. Topografi yang berupa daratan dengan ketinggian rata-rata 329 mdpl merupakan areal pertanian yang baik sehingga $80 \%$ penduduk bermatapencarian sebagi petani.

Sarana ibadah yang berada di wilayah Kelurahan Kedaung cukup banyak yaitu terdapat 5 mesjid dan 6 mushala. Sarana kesehatan juga cukup memadai yaitu terdapat 1 Puskesmas Pembantu dan 1 Poskeskel ditambah 2 Posyandu. Sarana pendidikan hanya terdapat 3 TK dan 1 PAUD saja dan tidak terdapat SD, SMP maupun SMA. Sarana perekonomian, tidak terdapat pasar, minimarket atau kelompok pertokoan. Di sektor perhubungan, tidak terdapat angkutan umum yang beroperasi keluar masuk wilayah Kelurahan Kedaung meskipun terdapat lokasi wisata alam Kamp 91.

Menurut Lurah Kedaung selaku Ketua Tim Relawan Desa Lawan Covid-19 sampai dengan bulan September 2020 belum ditemukan adanya kasus positif Covid-19 di wilayah kelurahan. Kepadatan penduduk yang rendah, tidak adanya transportasi umum, dan tidak adanya pemusatan kerumunan orang seperti pasar desa dan minimarket diduga menjadi hal yang menguntungkan bagi penduduk Kelurahan Kedaung sehingga risiko penularan Covid-19 sangat kecil. Kondisi tersebut tampaknya menjadikan sebagian penduduk menjadi kurang memberi perhatian terhadap potensi penularan Covid-19. Keadaan ini tergambar dari perilaku menggunakan masker ketika berada di luar rumah atau di tempat umum masih rendah $(<30 \%)$, masih ada sekitar $50 \%$ sarana umum yang belum dilengkapi sarana cuci tangan atau hand sanitizer dan minimnya media edukasi umum seperti spanduk yang berkaitan dengan Covid-19.

Di tingkat kelurahan sudah ada Tim Relawan Desa Lawan Covid-19 yang salah satu tugasnya adalam melakukan sosialisasi pencegahan Covid-19. Di setiap RT rutin dilaksanakan program Jumat Bersih, dan tingkat partisipasi masyarakat yang baik dalam berbagai kegiatan sosial kemasyarakatan merupakan potensi yang dapat dioptimalkan untuk meningkatkan kesadaran masyarakat dalam menerapkan protokol kesehatan. Meskipun demikian menurut Sekretaris Kelurahan Kedaung ada beberapa keterbatasan dalam mengembangkan potensi tersebut antara lain pengetahuan Tim Relawan dan masyarakat yang masih kurang khususnya yang berkaitan dengan pandemi Covid-19 serta terbatasnya anggaran untuk melaksanakan kegiatan dan menyediakan sarana pendukung pelaksanaan protokol kesehatan khususnya di tempat umum. Untuk menjawab permasalahan tersebut Tim Pengabdian Kepada Masyarakat Poltekkes Tanjungkarang melaksanakan kegiatan pengabdian kepada masyarakat di Kelurahan 
Kedaung dengan tujuan untuk meningkatkan kemampuan aparat dan masyarakat di Kelurahan Kedaung dalam pencegahan penyebaran Covid-19 melalui penerapan protokol kesehatan. Dengan kegiatan ini diharapkan Kelurahan Kedaung menjadi tangguh dalam menghadapi pandemi Covid-19.

\section{METODE}

Agar penerapan protokol kesehatan di masyarakat berjalan dengan baik diperlukan kesadaran dari semua unsur masyarakat. Falsafah preventif itu lebih baik daripada kuratif tampaknya perlu dipahamkan kepada masyarakat. Pemberdayaan lembaga dan komunitas sebagai penyuluh penerapan protokol kesehatan Covid-19 dipandang memiliki peran strategis yang kuat.[11] Selain itu program pemberdayaan komunitas efektif sebagai wadah menyalurkan informasi kepada anggota keluarga.[12] Karena itu kegiatan yang pengabdian kepada masyarakat yang dilakukan meliputi penguatan pengetahuan Tim Relawan Desa Lawan Covid19, memberikan edukasi bagi tokoh masyarakat, tokoh agama dan masyarakat kelompok rawan serta memberikan stimulan sarana pendukung pelaksanaan protokol kesehatan. Tim Relawan Desa Lawan Covid-19 diberi penyuluhan secara klasikal oleh Tim Pengabmas menggunakan media audio visual seperti video edukasi, leaflet dan flyer. Materi penyuluhan berisi tentang tugas pokok dan fungsi tim relawan khususnya dalam bidang edukasi kepada masyarakat, materi terkini tentang covid-19, dan penerapan protokol kesehan di masyarakat. Edukasi bagi tokoh masyarat, tokoh agama dilakukan secara kelompok di setiap RT oleh Tim Pengabmas yang bertanggungjawab pada setiap RT. Materi yang dibahas berbeda setiap kali pertemuan antara lain cara penggunaan masker yang baik, cara cuci tangan yang benar, adaptasi social \& physical distance serta peningkatan imunitas tubuh melalui makanan dan aktifitas fisik. Demikian pula dengan masyarakat kelompok rawan seperti lanjut usia dan ibu hamil dilakukan edukasi dengan materi serupa tetapi berbeda metodenya yaitu dengan cara konsultasi door to door. Kegiatan lainnya adalah pemberian stimulasi sarana pendukung pelaksanaan protokol kesehatan antara lain pemberian masker, hand sanitizer kepada masyarakat sasaran, serta pemberian alat cuci tangan untuk dipakai pada sarana umum. Ketercapaian kegiatan penyuluhan dan konsultasi diukur dengan menghitung peningkatan skor tes awal dan tes akhir sedangkan keberhasilan pemberian stimulus diukur dengan melakukan observasi tentang pemanfaatan sarana yang telah diberikan.

\section{HASIL DAN PEMBAHASAN}

a. Sosialisasi Kepada Tim Relawan

Sesuai dengan Surat Edaran Menteri Desa, Daerah Tertinggal dan Transmigrasi nomor 8 tahun 2020 tentang Desa Tanggap Covid-19, Kelurahan Kedaung telah membentuk tim Relawan Desa Lawan Covid-19 yang diketuai oleh Lurah dengan 24 anggota yang berasal dari perwakilan lembaga dan masyarakat seperti BPD, RW, RT, PKK, tokoh masyarakat, dan Bidan Desa. Sosialisasi yang telah dilakukan secara umum berhasil meningkatkan pengetahuan tim relawan rata-rata sebesar 42,3\%. Perbedaan skor pengetahuan tim relawan sebelum dan sesudah Sosialisasi dapat dilihat pada tabel 1.

Tabel 1 Skor Pengetahuan Tim Relawan Sebelum dan Sesudah Sosialisasi

\begin{tabular}{lccc}
\hline \multicolumn{1}{c}{ Statistik } & Pretest & Posttest & p-value* \\
\hline Mean & 66,25 & 91,67 & \\
Standar deviasi & 14,69 & 8,68 & 0,000 \\
Minimum-maksimum & $50-90$ & $80-10$ & \\
\hline
\end{tabular}

\footnotetext{
* Pair t-test
} 
Materi sosialisasi yang disampaikan kepada tin relawan ada 3 macam yaitu materi tentang tugas pokok dan fungsi tim relawan, materi tentang Covid-19, dan materi tentang protokol kesehatan. Hasil sosialisasi menunjukkan bahwa terjadi peningkatan di ketiga jenis pengetahuan tersebut dan peningkatan tertinggi pada pengetahuan tentang Covid-19 sebesar 49\%. Pengetahuan tentang protokol kesehatan dan tugas pokok fungsi tim relawan meningkat sebesar $42 \%$ dan 25\%. Rincian peningkatan pengetahuan dapat dilihat pada gambar 1 .

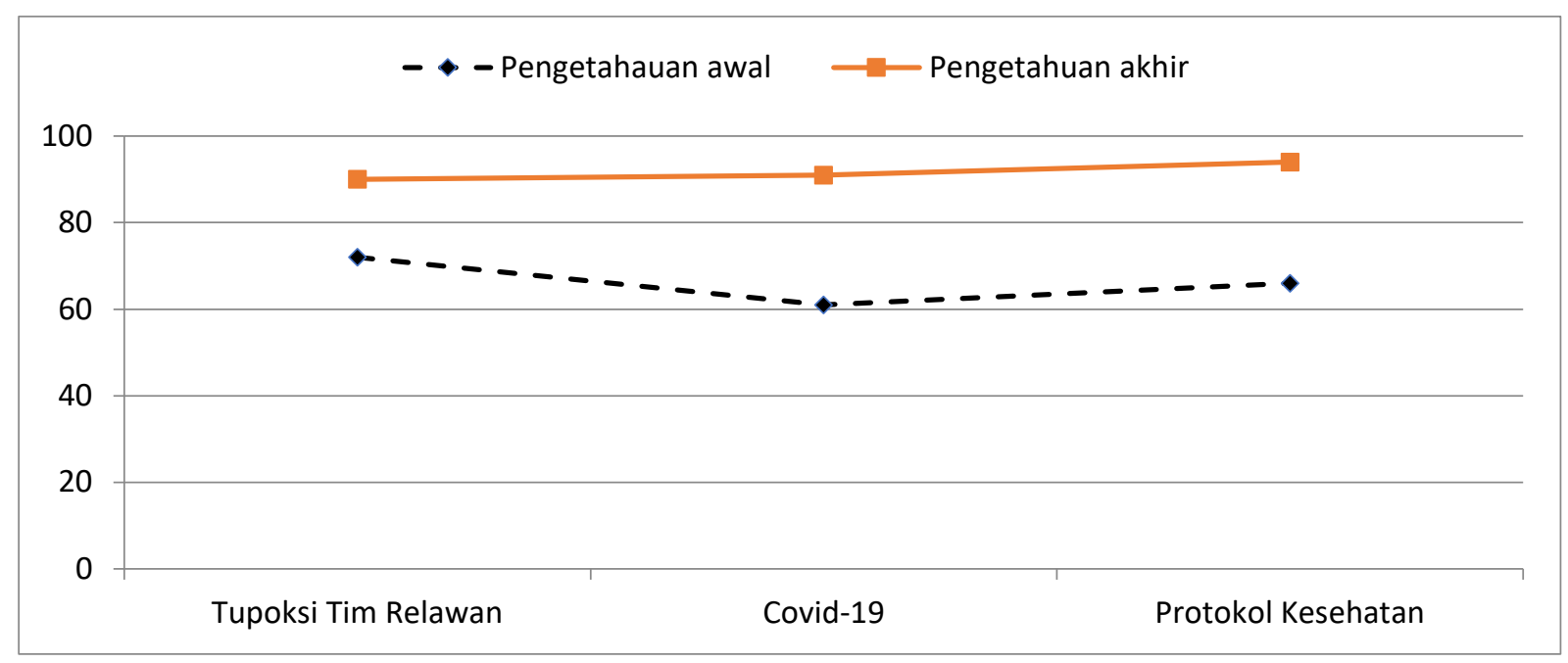

Gambar 1. Skor Pengetahuan Tim Relawan Menurut Jenis Pengetahuan Sebelum dan Sesudah Sosialisasi
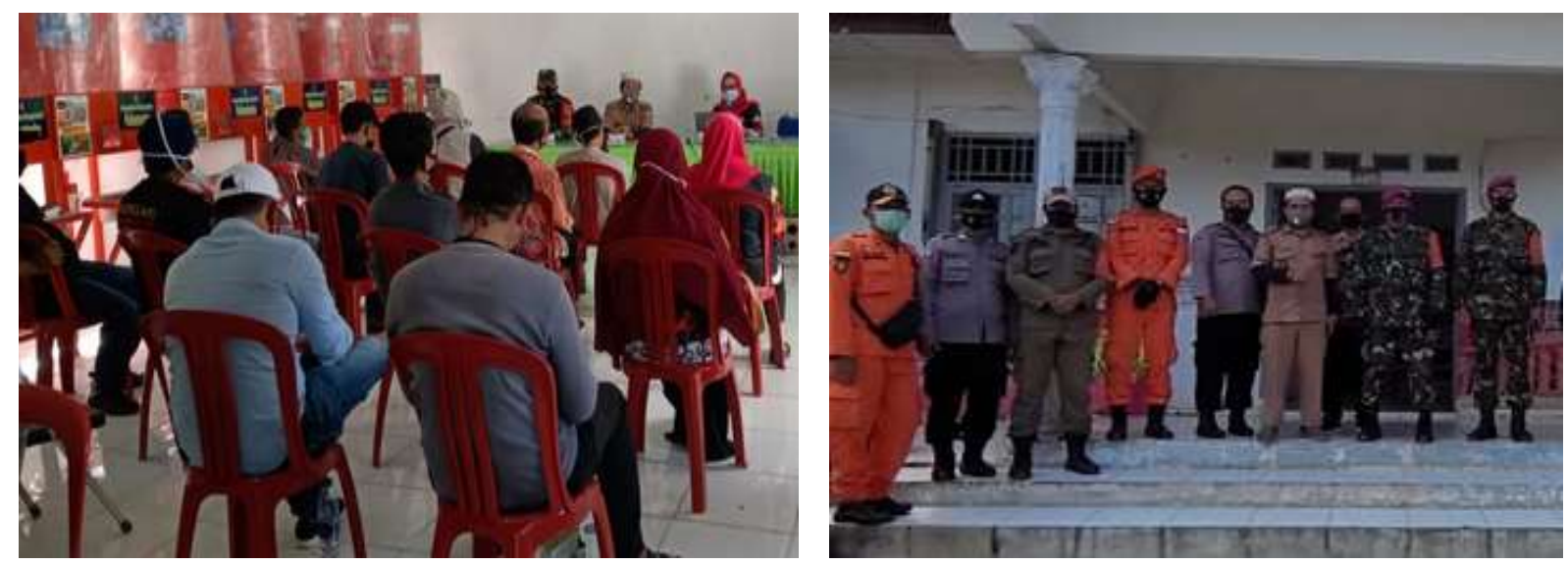

Gambar 2. Proses Sosialisasi Tim Relawan

\section{b. Penyuluhan dan Konsultasi Kepada Masyarakat}

Penyuluhan dengan sasaran tokoh masyarakat dan sebagian anggota masyarakat di setiap RT dilakukan melalui kelompok kecil. Peserta penyuluhan adalah pengurus RT, pengurus mesjid/mushala, tokoh masyarakat, dan anggota masyarakat lain seperti kelompok pemuda dan kelompok wanita. Penyuluhan informal dengan frekuensi sekali seminggu selama sebulan yang sebagian besar dilaksanakan di rumah Ketua RT ternyata lebih efektif dalam meningkatkan pengetahuan peserta penyuluhan. Tercatat sebanyak 210 orang dari 12 RT yang ada di Kelurahan Kedaung rata-rata pengetahuannya meningkat secara signifikan sebesar 52,03\% yaitu dari rata-rata 58,2 menjadi 86,4. Peningkatan tertinggi dicapai oleh RT2 LKII dengan 
peningkatan sebesar $63,6 \%$ dan peningkatan terendah dicapai oleh RT1 LKII dengan peningkatan sebesar 38,5\%. Penyuluhan juga berhasil memperkecil kesenjangan pengetahuan diantara peserta. Hasil pretest menunjukkan bahwa range skor rata-rata sebesar 40,8 dan hasil posttest menjadi 27,5 yang berarti pengetahuan peserta penyuluhan menjadi semakin homogen. Selain itu terjadi peningkatan pada nilai minimal dari peserta penyuluhan. Kondisi sebelum penyuluhan terdapat nilai terendah 30 dan setelah penyuluhan nilai terendah pengetahuan peserta penyuluhan meningkat menjadi 60 . Hasil skor pretest dan posttest peserta penyuluhan dapat dilihat pada tabel 2 .

Tabel 2 Peningkatan Skor Pengetahuan Peserta Penyuluhan Menurut RT/LK

\begin{tabular}{|c|c|c|c|c|c|}
\hline RT/LK & Skor & Pretest & Posttest & Peningkatan & $p$-value* \\
\hline \multirow{2}{*}{$01 / \mathrm{I}$} & Mean & 55,9 & 85,3 & $61,80 \%$ & 0,000 \\
\hline & Min-maks & $30-90$ & $80-100$ & & \\
\hline \multirow{2}{*}{$02 / \mathrm{I}$} & Mean & 65,6 & 93,8 & $48,30 \%$ & 0,000 \\
\hline & Min-maks & $40-90$ & 80-100 & & \\
\hline \multirow{2}{*}{ 03/I } & Mean & 55 & 81 & 48,2 & 0,000 \\
\hline & Min-maks & $40-70$ & $60-100$ & & \\
\hline \multirow{2}{*}{$04 / \mathrm{I}$} & Mean & 56 & 84,4 & $44,60 \%$ & 0,000 \\
\hline & Min-maks & $50-70$ & $70-90$ & & \\
\hline \multirow{2}{*}{$05 / I$} & Mean & 57,5 & 87,5 & $61,00 \%$ & 0,000 \\
\hline & Min-maks & $30-90$ & $60-100$ & & \\
\hline \multirow{2}{*}{$06 / \mathrm{I}$} & Mean & 57,5 & 85,5 & $48,70 \%$ & 0,000 \\
\hline & Min-maks & $40-80$ & $70-100$ & & \\
\hline \multirow{2}{*}{$07 / I$} & Mean & 59,5 & 87,5 & $47,10 \%$ & 0,000 \\
\hline & Min-maks & $50-80$ & $80-100$ & & \\
\hline \multirow{2}{*}{$08 / \mathrm{I}$} & Mean & 57,3 & 83,6 & $51,60 \%$ & 0,000 \\
\hline & Min-maks & $40-80$ & $70-100$ & & \\
\hline \multirow{2}{*}{$01 / \mathrm{II}$} & Mean & 67,5 & 93,5 & $38,50 \%$ & 0,000 \\
\hline & Min-maks & $50-90$ & $80-100$ & & \\
\hline \multirow{2}{*}{$02 / \mathrm{II}$} & Mean & 55,6 & 86,7 & $63,60 \%$ & 0,000 \\
\hline & Min-maks & $30-80$ & $60-100$ & & \\
\hline \multirow{2}{*}{ 03/II } & Mean & 57,5 & 86,5 & $50,40 \%$ & 0,000 \\
\hline & Min-maks & $40-80$ & $70-100$ & & \\
\hline \multirow{2}{*}{$04 / \mathrm{II}$} & Mean & 53,8 & 85,4 & 60,7 & 0,000 \\
\hline & Min-maks & $40-70$ & $70-90$ & & \\
\hline
\end{tabular}

* Pair t-test

Tim Pengabmas melakukan kunjungan rumah untuk menemui masyarakat kelompok rawan seperti kelompok usia lanjut, ibu hamil, dan keluarga yang memiliki anak balita. Di setiap RT. Anggota Tim Pengabmas melakukan penyuluhan dan konsultasi seputar masalah pencegahan penularan Covid-19. Selain itu juga memberikan peragaan penggunaan masker dan mencuci tangan atau menggunakan hand sanitizer yang benar. Setiap sasaran yang dikunjungi sekaligus diberikan bantuan masker dan hand sanitizer. Pada kegiatan pengabmas ini telah berhasil melakukan kunjungan rumah sebanyak 71 rumah tangga. Bantuan masker yang telah 
disalurkan sebanyak 500 buah, dan 100 botol hand sanitizer. Hasil observasi menunjukkan bahwa bantuan tersebut dimanfaatkan dengan baik oleh sasaran.
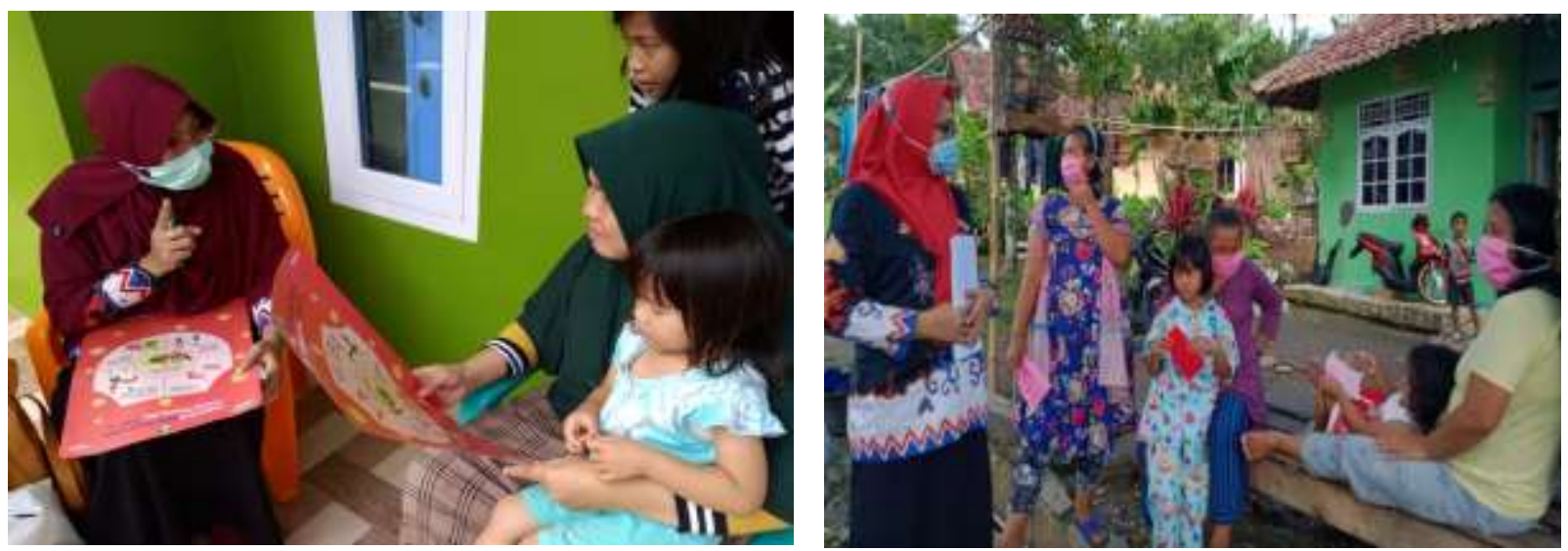

Gambar 4. Proses Konsultasi Kepada Masyarakat Kelompok Rawan

\section{c. Pemberian Stimulus}

Selain memberikan penyuluhan dan konsultasi, Tim Pengabmas juga menyerahkan bantuan alat cuci tangan kapasitas 500 liter sebanyak 10 unit kepada Kelurahan Kedaung. Bantuan tersebut selain untuk memenuhi sarana cuci tangan di tempat-tempat umum untuk merangsang partisipasi masyarakat untuk ikut menyediakan sarana cuci tangan dengan skala yang lebih kecil. Berdasarkan hasil observasi Tim Pengabmas, semua peralatan telah terpasang di tempat-tempat seperti mesjid, kantor kelurahan, Poskeskel, dan di gerbang perumahan. Instalasi airnya dikerjakan oleh masyarakat secara swadaya. Dilihat dari pemanfaatannya $100 \%$ telah dimanfaatkan oleh masyarakat setempat.
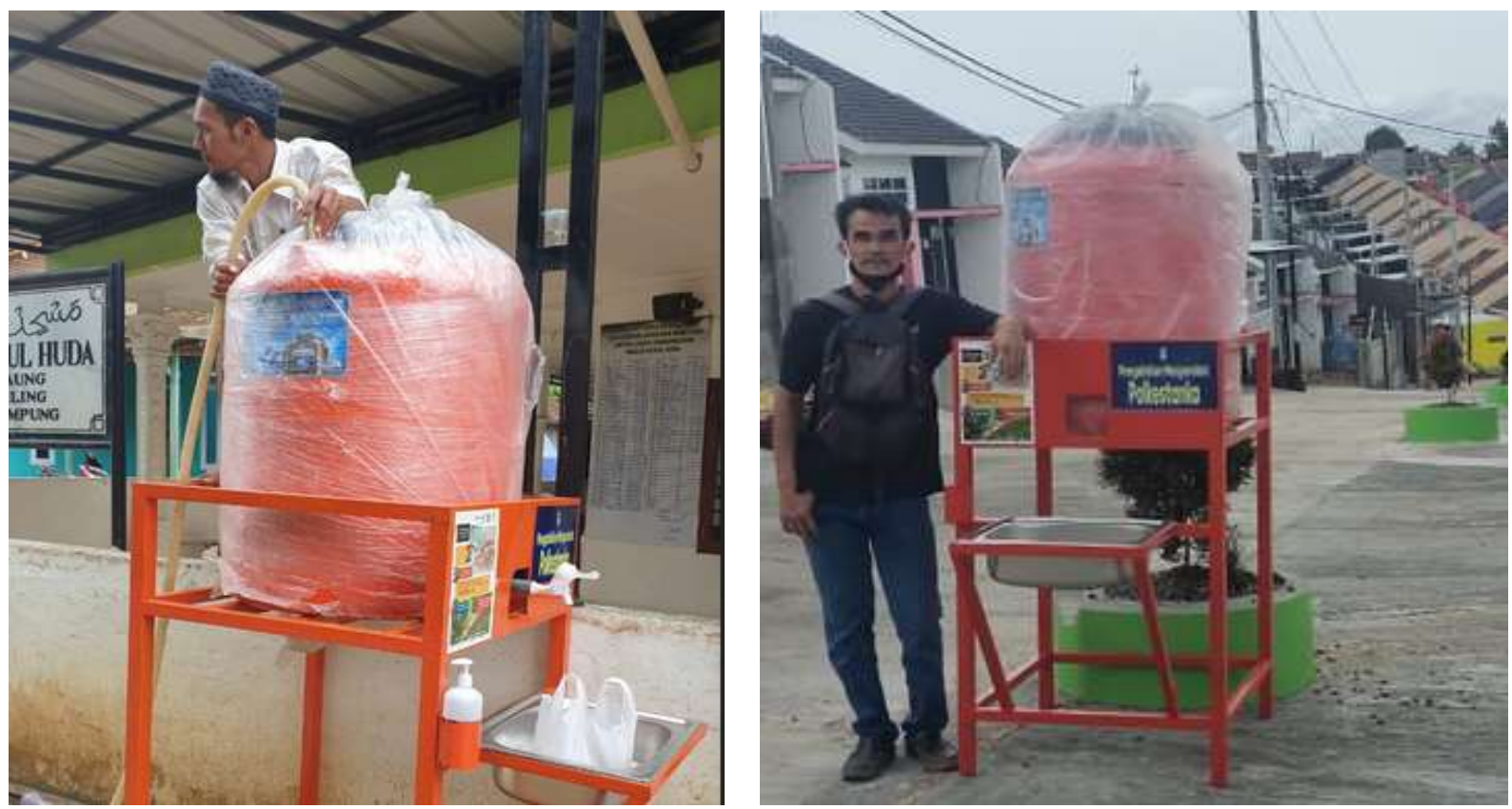

Gambar 5. Penempatan Bantuan Alat Cuci Tangan di Tempat Strategis

Tim Pengabmas juga melakukan pemasangan sanduk yang berisi himbauan yang berkaitan dengan pencegahan Covid-19. Spanduk dipasang di lokasi strategis di setiap RT yang 
berjumlah 12 RT. Selain itu juga memasang/menempelkan poster pada berbagai tempat di lingkungan RT sebagai media sosialisai tentang Covid-19. Ada 9 jenis poster yang disiapkan antara lain poster tentang tatacara pelaksanaan protokol kesehatan, himbauan makanan bergizi dan melakukan aktivitas fisik dan menjaga kebersihandiri dan lingkungan.

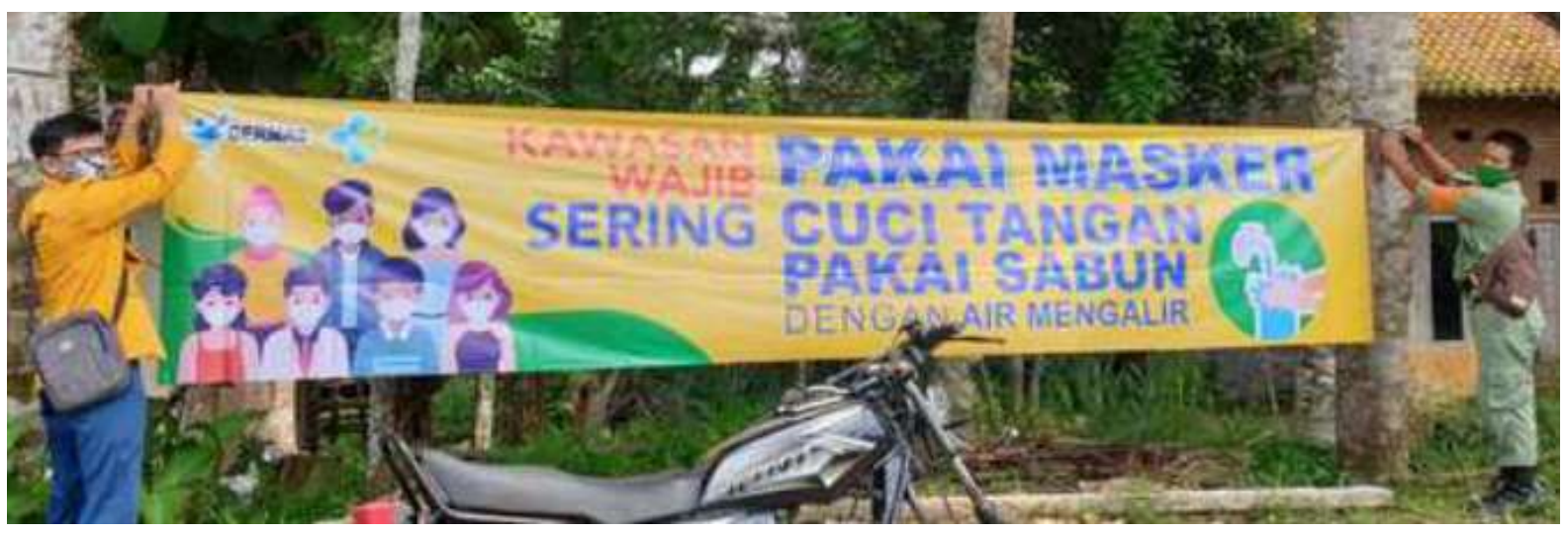

Gambar 6. Pemasangan Spanduk di Tempat Strategis
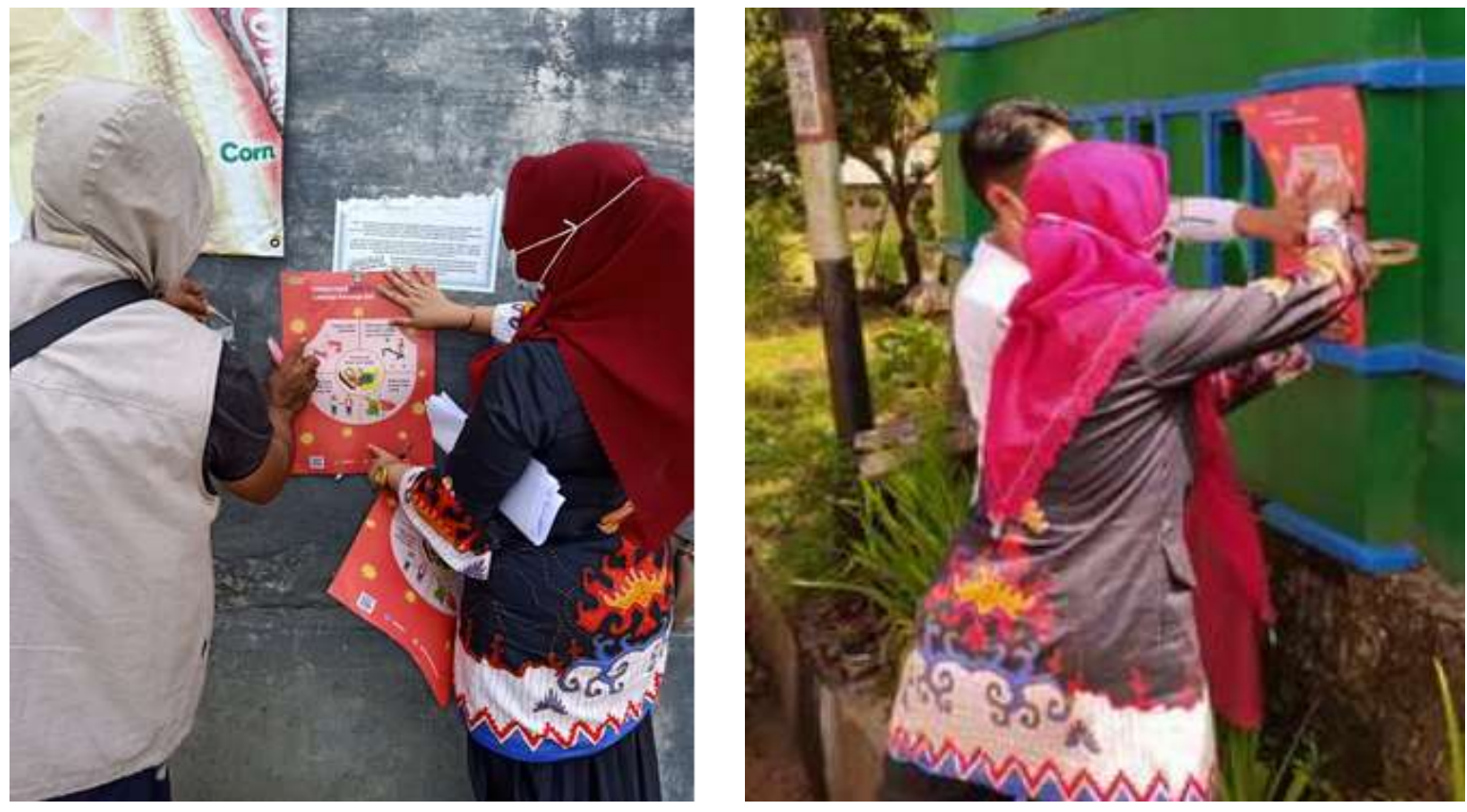

Gambar 6. Pemasangan Poster di Tempat Strategis

Perilaku individu dipengaruhi oleh pengetahuannya.[13] Kontribusi Tim Pengabmas melalui kegiatan sosialisasi, penyuluhan dan konsultasi diharapkan dapat memperlancar akses informasi sehingga masyararakan akan mendapatkan pengetahuan yang baik dan benar. Dengan terjadinya pandemi setiap orang perlu merubah perilaku atau melakukan adaptasi agar terhindar dari tertular Covid-19 yang sekaligus berkontribusi terhadap pemutusan rantai penularan kepada masyarakat yang lebih luas. Adaptasi kebiasaan baru membutuhkan informasi yang baru dan terpercaya oleh karena itu peningkatan pengetahuan yang sudah dicapai sebagian masyarakat di Kelurahan Kedaung diharapkan mampu memicu kesadaran dalam menerapkan protokol kesehatan. Modal sosial yang selama ini telah dimiliki masyarakat seperti gerakan kebersamaan, saling menjaga keamanan, dan partisipasi masyarakat dalam bidang kesehatan di masa pandemi ini perlu diaktualisasikan kembali dengan lebih terfokus. 
Partisipasi, keterlibatan masyarakat melalui RT dan kelompok-kelompok masyarakat lainnya misalnya ibu- ibu dasa wisma memperlihatkan adanya kesadaran diri setiap warga untuk ikut terlibat dalam segala urusan yang menyangkut diri dan lingkungan mereka. Secara swadaya bersama melaksanakan berbagai kegiatan, misalnya; pengadaan masker untuk warga masyarakat dan penetapan kesepakatan wajib menggunakan masker saat di luar rumah. Pada tingkat kelurahan dilakukan pembelian cairan disinfeksi yang secara berkala disemprotkan ke lingkungan, pengadaan perangkat cuci tangan pada tempat-tempat strategis di lingkungan tempat tinggal, pemeriksaan suhu tubuh, kewajiban cuci tangan bagi tamu diwilayah tempat tinggal, dan sebagainya.

\section{KESIMPULAN}

Kegiatan pengabdian kepada masyarakat di Kelurahan Kedaung, Kota Bandar Lampung telah dilakukan selama lebih kurang tiga bulan. Kegiatan sosialisasi kepada Tim Relawan yang fokus pada upaya pencegahan penularan Covid-19 berhasil meningkatkan pengetahuan anggota Tim Relawan secara signifikan. Penyuluhan dan konsultasi berkala dengan fokus pengetahuan yang sama juga dapat meningkatkan pengetahuan sasaran di masyarakat. Selain itu dengan pemberian bantuan stimulus sarana pelaksanaan protokol kesehatan juga mampu menggerakkan masyarakat untuk terlibat dalam pemanfaatan, perawatan dan penyediaan sarana sejenis dengan kapasitas yang lebih kecil.

\section{UCAPAN TERIMA KASIH}

Pelaksanaan kegiatan pengabdian kepada masyarakat ini sepenuhnya digagas dan didanai oleh Poltekkes Tanjungkarang. Oleh karena itu Tim Pengabmas mengucapkan terima kasih kepada Direktur dan Unsur Pimpinan Poltekkes Tanjungkarang yang telah memberikan fasilitas tersebut. Tim Pengabmas juga mengucapkan terima kasih Kepada Lurah Kedaung beserta jajarannya yang telah bersedia bekerjasama dalam kegiatan pengabdian kepada masyarakat di wilayah Kelurahan Kedaung, Kota Bandar Lampung.

\section{DAFTAR PUSTAKA}

[1] M. A. Shereen, S. Khan, A. Kazmi, N. Bashir, \& R. Siddique, "COVID-19 infection: Origin, transmission, and characteristics of human coronaviruses," Journal of Advanced Research, 24, 91-98, 2020, doi : https://doi.org/10.1016/j.jare.2020.03.005

[2] T. Bedford, "Cryptic transmission of novel coronavirus revealed by genomic epidemiology," bedford lab, 2020 [Online]. Available: https://bedford.io/blog/ncovcryptic-transmission/

[3] R. Li, S. Pei, B. Chen, Y. Song, T. Zhang, W. Yang, \& J. Shaman. "Substantial undocumented infection facilitates the rapid dissemination of novel coronavirus (SARS-CoV-2)". Science, 368(6490), 489-493, 2020, doi: https://doi.org/10.1126/science.abb3221

[4] T. Singhal, "A Review of Coronavirus Disease-2019 (COVID-19)," Indian Journal of Pediatrics, 87(4), 281-286, 2020, doi: https://doi.org/10.1007/s12098-020-03263-6

[5] World Health Organization. Anjuran mengenai penggunaan masker dalam konteks COVID19. World Health Organization, April, 2020, p. 1-6.

[6] J. Liu, X. Liao, S. Qian, J. Yuan, F. Wang, Y. Liu, et al. "Community Transmission of Severe Acute Respiratory Syndrome Coronavirus 2, Shenzhen, China", Emerg Infect Dis., 26(6),1320-1323, 2020, doi: https:/doi.org/10.3201/eid2606.200239

[7] Coronavirus disease 2019 (Covid-19) Situation Report - 73. Jenewa: World Health Organization; 2020 [Online] (https://www.who.int/docs/defaultsource/coronaviruse/situation-reports/20200402-sitrep-73-covid19.pdf?sfvrsn=5ae25bc7 6). 
[8] VCC Cheng, SC Wong, JHK Chen, CCY Yip, VWM Chuang, OTY Tsang, et al. "Escalating infection control response to the rapidly evolving epidemiology of the coronavirus disease 2019 (COVID-19) due to SARS-CoV-2 in Hong Kong". Infect Control Hosp Epidemiol, 41(5), 493-8, 2020, doi: https://dx.doi.org/10.1017/ice.2020.58

[9] F. Di Gennaro, D. Pizzol, C. Marotta, M. Antunes, V. Racalbuto, N. Veronese, and L. Smith, "Coronavirus Diseases (COVID-19) Current Status and Future Perspectives: A Narrative Review," International Journal of Environmental Research and Public Health, vol. 17, no. 8, p. 2690, April 2020, doi: https://doi.org/10.3390/ijerph17082690

[10] Mohammad Mulyadi. Partisipasi Masyarakat Dalam Penanganan Penyebaran Covid-19. Pusat Penelitian Badan Keahlian DPR RI. Info Singkat Vol. XII, No.8/II/Puslit/April/2020

[11] L. Farokhah, Y. Ubaidillah, \& R. A. Yulianti, "Penyuluhan Disiplin Protokol Kesehatan Covid19 Di Kelurahan Gandul Kecamatan Cinere Kota Depok," Prosiding Seminar Nasional Pengabdian Masyarakat LPPM UMJ, 1(1), 2020.

[12] D. Z. Syah, D. Utari, and T. Adinugraha, "Edukasi Penerapan Protokol Kesehatan Penyelenggaraan Kegiatan Pada Masa Pandemi Covid 19 di TPQ Masjid Awalulmu'minin Gamping", jpmkh, vol. 2, no. 2, pp. 28 - 33, Oct. 2020.

[13] Erisandi Arditama, Puji Lestari, Tonggo Jogo, "Membangkitkan kesadaran dan ketaatan warga berbasis kearifan lokal pada masa pandemi Covid-19 di Jawa Tengah", Jurnal Pendidikan Kewarganegaraan Undiksha, vol 8, no. 2, pp. 157-167, 2020, doi: http://dx.doi.org/10.23887/jpku.v8i2.25434 